\title{
The Degree to Which the School Principals of Public Schools in the Kasbah of Salt Possess Schools' Crisis Management Skills from the View Point of Counselors
}

\author{
Eman B. Alhussein \\ Khowla A. Ghnaim \\ Nagham Abu Albasal \\ AL Balqa Applied University, \\ Princess Rahma University College, Jordan
}

DOI: https://doi.org/10.36941/jesr-2020-0097

\begin{abstract}
This study aimed to investigate the degree to which the principals of public schools in the Kasbah of Salt possess the skills of school crisis management from the viewpoint of the counselors, and the study sample consisted of (75) counselors, who were randomly chosen during the second semester of the academic year 2019-2020. The descriptive approach was used where the researcher prepared a questionnaire consisting of (52) items, distributed on four domains of crisis management skills (preventive skills to avoid the occurrence of the crisis, planning skills to face the crisis, administrative skills to deal with the crisis during its occurrence and administrative skills (treatment) after the crisis ended. Its validity and reliability were verified. The study results showed that the degree of educational principals' possession of school crisis management skills was moderate. The results also showed statistically significant differences in the degree of principals' possession of school crisis management skills attributed to gender in favor of males. The results also showed statistically significant differences in the degree of possession due to the variable of experience, and the absence of statistically significant differences attributable to the variable of academic qualification, educational stage, some recommendations were made in light of the results of the study.
\end{abstract}

Keywords: School Principals, Skills, School Crises, Degree of Possession

\section{Introduction and Theoretical Framework}

The challenges of the information revolution and technological progress impose on all institutions, especially educational institutions, to put in place organized, studied, and conscious scientific plans to prevent crises and disasters in every profession, then training in facing crises and disasters in light of the optimum level according to the capabilities of each institution, and this means that the formation of the work team in order to face crises and disasters is no longer a social luxury, instead, it has become an imperative necessity to be prepared for, and the school crisis is an unexpected situation or event that students, teachers, administrators, and the local community can be exposed to, and it will be the result of performance disturbances and pressures that threaten the existence of the school and its entity, and may lead to problems, conflicts, or clashes, which requires taking 
practical procedures for a fundamental solution to them through the organization of ACFA for communication, information, human resources and operational processes, crisis management is "a purposeful activity based on research and obtaining the necessary information that enables the administration to predict the locations and trends of the expected crisis, and to create an appropriate climate for dealing with it, by taking measures to control and eliminate the expected crisis or change its course for the benefit of the organization" (Ahmed, 2002). Abu Qahf defined it as "a group of preparations and administrative efforts made to confront or limit the negative effects of the crisis" (Abu Qahf, 2002).Crisis management also means "dealing with crises to avoid their occurrence through planning for avoidable situations, and making preparations for crises that can be expected to occur within the framework of a system that applies with these emergencies when they occur to control the results, or reduce their destructive effects" (Al-Aarji and Daqamsa, 200o).

The school administration is nothing but coordinated efforts and activities carried out by the school staff. The school principal is considered one of the most essential elements and people; instead, he is the pillar of the educational process, and the educational system depends on him to achieve its goals. The principal is the first administrative in the school, he is the direct head of all school employees, and he is primarily responsible for the school's success in achieving its goals and raising its pupils, he represents a constant link in school relations of all kinds between teachers, teachers and students, parents and teachers, and between mentors and the teachers, he is always at the center of the educational process, he has the burden of organizing it to get the best possible results. He is the one who guides the drawing and implementation of various plans" (Ahmad, 2002).

The principal of the school is considered the main person capable of implementing the educational policy that seeks to make progress in the school, and here comes the importance of the participation of his employees in developing programs and systems that it wishes to implement and achieve in the school to bring about a desirable change. Without the positive participation of the headmaster in that work, it is challenging to implement and achieve the desired goals (Jamal and Hakim, 1983). The school principal is an educational leader and the first administrative in his school who is the head of the school administration and the process of directing, supervising and following up on its activities (Rabi', 2006).Therefore, he must have the leadership qualities that make him the right person to lead and direct the institution to achieve the goals set for it in the best possible way.

Crisis management and school confrontation is a multi-faceted process that includes multiple activities. Hence, crisis management requires innovative methods, conscious management, and an unusual leadership style. Whatever type of crisis will be dealt with, there are several standard requirements for successful and effective crisis management which are (Ashour, 2011):

\subsection{Planning as a fundamental principle}

Planning for crisis management is the framework within which its scope is dealt with, and it means pre-determining what needs to be done, how and when it can be done. Hence, planning is linked to the facts of the crisis, and scenarios for future situations, anticipating events, preparing for facing them, and drawing scenarios to track activities and actions to address crises facing the institution as effectively and efficiently as possible (Obaid, 2010).

\section{2}

\section{Crisis management team}

The crisis management team is defined as a group of individuals that meets to help plan and manage it and includes the following:

- Director and agent: their function is to manage procedures.

- Teachers: It is their responsibility to keep students safe.

- Secretarial: It is responsible for students who assign to them the time of training in crisis management or rehearsal. They must assist the director and agent in implementing security measures. 
- Maintenance members: They are responsible for emergency devices, providing supplies, and using available facilities.

- Students: They are responsible for their security at all times, and they must not endanger themselves, other students, or the rest of the school personnel.

\subsection{Determine the appropriate policy}

In the sense of providing a clear framework for action, in which opportunities for managing the crisis increase effectively in the event of an action plan at the regional level, and the presence of leadership is necessary to support effective implementation and follow-up readiness, as far as its efficiency, experience, and knowledge of all aspects of the crisis are concerned, its success in managing the crisis is determined. The main responsibility for effective leadership is to summarize the facts about the crisis, analyze its causes, take active measures and means to avoid human and material losses, and draw lessons to prevent crises from occurring or recurring (Abdullah, 2012).

The role of school principals in managing school crises:

The responsibilities of school principals in managing school crises can be defined here, which are based on the following steps (Al-Shuraida and Al-Araji, 2013).

a. Planning: This is done through preparing scenarios and perceptions about possible crises, and taking appropriate preventive measures that work to prevent the causes of crises, as well as developing and equipping a crisis management team at the school.

b. Organizing: Confronting crises need a collective effort, and therefore there is a need for coordination, compatibility, and complementarity between the various efforts that are made in managing the crisis, to prevent duplication and inconsistency in implementation, and the organization is done through the distribution of tasks and roles to the school crisis management team.

c. Simplification of procedures: In light of the limited time and the acceleration of crisis events, it is necessary to use simple procedures that help in dealing with the crisis, and to avoid routine work and written communications due to the importance of time during crises in schools.

d. Decision-making: School crisis management needs urgent speed in making accurate and appropriate decisions of the crisis so that decisions are clear and can be implemented within the limits of the available capabilities in the school.

Starting from the new direction of the school's role and its importance as a basic unit in building and developing society, the principal is no longer just a system implementer, nor is he merely based on the preservation of furniture or the monitoring of homework. Rather, he has become a leader of the school, possesses necessary skills and is in-depth with a scientific background, competence and management ability. Nevertheless, the process of administrative leadership depends not only on the principal of the school, regardless of his characteristics, but also on the group members that the leader deals with and on the level of human relations between them. Hence the educational counselor's role in creating bridges of trust and warmth in human relations with the school principal is evident to be able to assess the degree of his administrative skills in general and crisis management skills in particular, as the principal of the school contributes to achieving the educational goals is not only limited to his performance of his routine duties, rather, the school principal must be able to take on difficulties and risks, to be able to make a bold decision. The importance of school crisis management in the school principal is evident, which enables the researchers to conduct a study to reveal the degree of public-school principals in Kasbah Al-Salt possession of school crisis management skills from the viewpoint of the counselors. The school principals were evaluated from the viewpoint of a group that plays a large role in the educational process, as the counseling services are among the finest services provided to individuals and require cooperation between the school administration and the educational counselor. 


\section{Previous Studies}

After reviewing the previous relevant Arab and foreign studies, the researchers considered its arrangement from the oldest to the most recent as follows:

Hamdouneh (2006) study aimed to identify the practice of the school principals of high schools in Gaza Governorate for crisis management skill. The researcher used the descriptive method and its tool the questionnaire which is consisting of (6o) items; the study sample consisted of (36) school principals, the results showed that high school principals practiced the skill of crisis management largely and effectively, and the results also showed that there were no statistically significant differences about the practice of the high school principals of the crisis management skill due to gender and years of experience variables.

Adamson and Buckcock (2007) study, which aimed to identify the views of psychologists in American public schools on plans and teams to deal with crises, on a sample of (228) psychologists. The results showed that most specialists emphasized the existence of plans to deal with crises in their schools, and $83.6 \%$ of them emphasized the presence of crisis management teams in their schools. The results also showed that it is concerned with helping students and workers and dealing with the media, as it was found that $93 \%$ of specialists have faced severe crises in their schools, and $98.2 \%$ of specialists receive some kind of specialized training in dealing with crises. The study suggested training workers and teachers to deal with crises and finding ways to improve crisis response plans.

Wilson and Keith (2007) study aimed to identify the types of crises faced by high schools' principals in the United States of America, and how they manage these crises. Among the most important findings of the study is that there is a group of crises facing the school, such as shooting, stabbing with sharp machines, killing of all kinds, terrorist activity, and suicide due to these crises. The results confirmed that proper planning helps school principals to better manage crises to clarify goals and roles and that a database of students and workers helps protect students, the study also recommended the need for a special crisis management team, which includes the team leader and an assistant with the importance of the clear and safe distribution of roles.

Saqr (2009)study aimed to reveal the most important skills needed for principals of UNRWA schools for crisis management and ways to develop them; the study sample consisted of (221) school principals. The researcher prepared a questionnaire consisting of (58) items distributed in (5) domains. The results of the study concluded that the crisis management skills of the UNRWA school principals are available largely and effectively, the results showed that there were no statistically significant differences between the averages of the sample's estimates about the degree of availability of crisis management skills for UNRWA school principals due to gender, educational qualification, academic level, and experience variables.

Dmitry and Dunya's (2009) study aimed to identify the roles assigned to teachers, police officers, the family, and the student himself in the crisis resulting from the school shooting incidents, and to deal with their roots, motives, and repercussions. The case was studied at the junior high school on the island of Malvinas in the Argentine state in April 2009. The study concluded that the police and the concerned security services should play their role in accidents as it is not within the school's jurisdiction to follow them. Still, the school administration, its teachers and students have an important role to play in setting up a mechanism to eradicate violence from schools and put adequate preventive means to prevent any such events in schools. The study also focused on the role of security services and health departments in diagnosing cases in schools and treating them in cooperation with the competent authorities.

Jenny (2009) study aimed to identify the reality of crisis management in a selected sample of American schools, and the study confirmed that these schools are exposed to several natural and economic crises, and it became clear through the results of the study that there are no limits to the crises to which educational institutions are exposed. Therefore, the study recommended the necessity of strengthening the state of preparedness for crisis management in educational institutions.

Liming's (2010)study aimed to identify the most critical problems facing high school principals 
in public schools in Manchester County in Britain, and the study was applied to a sample of (24) principals. A form was distributed to them that included the problems facing school administration in the following areas; the educational system domain, the students' domain, the teaching staff domain, and the community domain, and the results showed that school administrators face problems in the four domains with a moderate degree, the results also showed that there are differences in the level and quality of problems according to the gender variable and in favor of males, and the absence of differences in the level and quality of problems according to the variables of experience, and the educational qualification.

Faraj (2011) study aimed to identify the extent to which female principals practice school crisis management skills from the viewpoint of both female and male teachers in general education schools for girls in the city of Makkah Al-Mukarramah and the researcher used the descriptive survey method, the results of the study concluded that the public education school principals practice the skill of school crisis management was (high) for the skills of time management and innovative thinking and with a degree (very high) for the skill of facing stress, the skill of developing team spirit and teamwork, the skill of communication, while the teachers' response was that the principals practice the skill of school crisis management with a degree (high), there are statistically significant differences at the level of (0.05) between the study population answers from female principals and teachers, about the extent to which public school principals practice the skill of school crisis management due to the job variable and these differences were in favor of the female principals.

Patterson (2012) conducted a study entitled "School Crisis Intervention Programs" The study aimed to identify the role of educational leaders in ensuring security and safety and undermine the implementation of violence in the schoolyard, and the study used the descriptive approach, as used for questioning. The study concluded that educational leaders should use their available resources and address the situation effectively.

Al-Zoubi (2014) conducted a study aimed to identify the degree of availability of elements of crisis management in the directorates of education in the Irbid Governorate from the viewpoint of the department heads in them. The descriptive and analytical method was used by designing a questionnaire consisted of (34) items, the study sample consisted of (37) department heads in the directorates of education in the Irbid governorate. The results of the study showed the availability of the elements of crisis management in the directorates of education in the Irbid governorate to a high degree, and the absence of statistically significant differences in the degree of availability of the elements of crisis management due to gender and experience variables.

Udo (2014) conducted a study entitled "Managing student crises in institutions of higher education and proposing ways to confront them", and the study aimed to identify the distinctive factors for dealing with educational crises within higher education institutions and suggest ways to address them, the study used the descriptive and experimental method, as the questionnaire was used. The study concluded that there are no statistically significant differences between the opinions of students (male-female) regarding the causes of student crises in higher education institutions. The study also concluded that there are no statistically significant differences between the average students' scores on the scale of student crisis management strategies.

Al-Hazaymeh (2014)study aimed to reveal the capabilities of school principals in Irbid governorate in dealing with crises occurring in their schools, the researcher used the descriptive approach, a questionnaire consisting of (50) items was applied, the study sample consisted of (241) male and female principals. The results showed that the ability of school principals to deal with crises is moderate, and the results also showed that there are no statistically significant differences in the capacities of school principals in Irbid Governorate to deal with crises due to the gender variable.

Saras (2015) conducted a study aimed to identify the reality of crisis management in private schools in the governorates of Bethlehem and Ramallah from the viewpoint of its teachers and administrators. The sample of the study consisted of (82) male and female principals and (198) male and female teachers. The results indicated that the reality of crisis management in private schools was good. The results also showed that there are no differences between the estimates of the 
members of the study sample for the reality of crisis management in private schools due to gender variations, educational qualification, the number of years of work, governorate. Still, there were differences between sample estimates relating the reality of crisis management in private schools is attributed to the variable of the job title, and the differences were in favor of the male principals.

Khalil (2016) conducted a study aimed at knowing the reality of crisis management in Palestinian government schools from the viewpoint of administrators, and the researcher built the study tool as it consisted of (48) items distributed into three domains, the study sample consisted of (140) male and female principals, and the results of the study showed that the reality of crisis management in Palestinian government schools is high, the results also showed the presence of statistically significant differences between the averages of the reality of crisis management in Palestinian government schools due to the gender variable and in favor of females, the existence of differences attributable to the variable of the educational qualification and in favor of a bachelor's degree and the existence of differences attributed to the variable years of experience and in favor of (11) and more.

Gaddafi (2017) conducted a study aimed at knowing the strategies of confronting educational crises in secondary education schools in Libya from the viewpoint of school principals and arriving at the proposed measures to activate strategies to confront crisis management, the descriptive approach was used, and an open interview form was prepared to identify strategies to confront educational crisis management. The study concluded the need to provide a database with information that helps to manage educational crises, establish a crisis management unit in secondary schools and work to activate it, develop plans and scenarios to confront crises.

Al-Mashaqba (2018) conducted a study aimed at revealing the degree of school principals in Zarqa Governorate possessing the skill of managing school crises from their viewpoint, to achieve the goals of the study the researcher built performance of the study consisting of (24) items, the sample of the study consisted of (125) male and female principals in Zarqa Governorate. The results indicated that the degree of directors of government schools in Zarqa Governorate possession of the skill of school crisis management was high. The results also showed no statistically significant differences in the degree of school principals' skill of school crisis management attributed to the gender variable.

\subsection{The previous studies show the following}

1. A number of these studies focus on the skills necessary for principals in dealing with school crises and their relationship to several variables such as the study (Hamdouna, 2006), Khalil study (2017), and Saqr's study (2009). The current study focused on selecting school crisis management skills and the degree of principals' ownership of it and its relationship to gender, educational qualification, experience, and educational stage.

2. In all of these studies, the sample was the principal, except for the Sarras study (2015) appointed by the directors and teachers, while the current study was appointed by the educational counselors.

3. Previous studies were in different environments, some in Jordan, such as Al-Hazaymeh (2014), and Al-Mashaqaba Study (2018). This study was conducted in Jordan, some in Saudi Arabia, such as the Faraj study (2011), and some in Palestine, such as the Sarras study (2015), and some in Libya, such as the Mahdi (2017).

4. All Arab studies focused on the degree to which principals have principal skills in dealing with crises, except for the study of Al-Azabi (2014) focused on elements of school crisis management, and the Mahdi study (2017) focused on the strategies needed to face the crisis, and this study focused on principals have the skills to deal with school crises.

5. All studies used a questionnaire as a study tool, which was done by the current study, except for the study of Al-Mahdi (2017) he used the open interview. 


\subsection{The current study is distinguished from previous studies in the following:}

It is the only scientific study (within the limits of the researcher's knowledge) that dealt with the degree of principals' skills in managing the handling of school crises in the Kasbah Al-Salt from the viewpoint of the counselors, the researcher benefited from the previous studies in the theoretical framework, study design, determining its independent and dependent variables, preparing the questionnaire, and in presenting and discussing the results.

\section{The Problem of the Study and its Questions}

Dealing with school crises is one of the main drivers, in which the effectiveness of management appears in emergency situations that largely determine the principal's ability to analyze the crisis and take decisions to confront it, that ability is embodied in assessing the crisis situation, analyzing the crisis, scientific planning for intervention in the crisis, and the actual intervention to address the crisis, so the need to manage school crises has become necessary, the presence of principals of crisis management has become essential to help students face the crises and problems facing them, through the principal possessing skills that go beyond traditional skills, personal and performance skills to deal with crises faced by individuals and groups working within the scope of his school and help them to overcome the near and long-term psychological effects they face as a result of those the crisis, hence the interest in evaluating the degree of school principals possessing the necessary skills in dealing with crises in public schools in the Kasbah of Salt and identifying the reality of these skills to be an indication of the training needs of the school principal during service, and the role of the competent authorities towards these needs to develop administrative services, and given the importance of crisis management owned by the director, in improving the services provided to workers within the educational institution. The authorities involved in preparing and training principals have endeavored to provide them with the skills of crisis management, to meet the challenges of contemporary education. Through the work of the researcher, she noticed that there is little employment for crisis management, despite the Ministry of Education's endeavor to hold continuous courses to train principals in possessing administrative skills in dealing with crises effectively to be used in the educational process, in addition to the lack of studies that dealt with the issue of crisis management skills and the degree of educational principals possessing it, this study came to know the degree of schools administrators possession in the Kasbah of Al-Salt School of crisis Management skills from the counselors' viewpoint.

In light of this, the study problem can be identified in answering the following questions:

The first question: What is the degree to which school principals of public schools in the Kasbah of Salt possess the skills of school crisis management from the viewpoint of the counselors?

The second question: Are there statistically significant differences at the level of significance ( $\alpha$ $=0.05)$ in the degree of principals of public schools in the Kasbah of Salt possessing school crisis management skills from the viewpoint of counselors attributable to the gender variable,(educational experience), (educational qualification), (educational stage)?

\subsection{The Importance of the Study}

The study's importance stems from the fact that it reveals the principal's skills in dealing with school crises and the role that the principal plays in dealing with all elements of the educational process; therefore, the theoretical importance of this study lies as follows:

1. It provides a theoretical framework in school crisis management, which school principals may benefit in improving their skills and helping researchers to conduct more studies that address the skills of dealing with school crises and their relationship to some variables.

2. Define a list of school crisis management skills that must be possessed by school principals.

3. To diagnose the current reality of the degree of school principals having the necessary skills 
in dealing with school crises, and in addressing deficiencies, if any, to better use these skills in the educational process.

4. To respond to recommendations of research, studies, and conferences regarding the necessity of paying attention to managing school crises in a way that serves the educational process in schools.

5. To enrich educational literature and open the way for new studies concerned with school crisis management skills in different regions.

6. To build training programs for school principals on how to employ crisis management skills with workers within the educational institution to alleviate the severity of their crisis.

\subsection{Objectives of the study}

1. Identify the skills of school crisis management and the degree to which principals in government schools have them in light of some variables.

2. Explain the differences in the degree to which school principals have the necessary skills in dealing with school crises in light of the variables of gender, experience, educational qualification, and educational stage.

\subsection{Procedural definitions of terms}

Skills: It is a set of techniques that the principal possesses and uses during the administrative process, such as planning skill, organization skill, follow-up skill, guidance, and control skill (Al-Mashaqaba, 2018), and it is defined procedurally in this study as the degree obtained by the director, on the scale of skills needed in Dealing with school crises used in this study.

Crises: It is a sudden situation or a turning point that leads to unstable situations, and undesirable consequences occur in a short time, and it requires taking a specific decision to confront at a time when the concerned parties are not ready or unable to face (Saqr, 2009), the researcher defines it procedurally as an emergency of disturbance experienced by the school principal and constitutes a threat to him and the elements of the educational process, either inside or outside the school, affecting the course of school work, needs skills to overcome it.

Degree of possession: It is the degree to which school administrators recruit and practice school crisis management skills, and it is measured by the degree of response to the degree tool relating principals' possession of school crisis management skills.

Director: The person responsible for administrative and technical work in the school, and provides school management services to develop all elements of the educational environment, and is appointed by the Ministry of Education to carry out the management process, in this study is the director who works in government schools of the Directorate of Education in the Kasbah of Salt.

\subsection{The limits of the study}

a. Time limits: The study was conducted in the second semester of 2019-2020.

b. Spatial limits: The study was conducted in public schools at the Kasbah of Salt Directorate of Education.

c. Human limits: This study was conducted on (75) female and male mentors in public schools in the Kasbah of Salt.

\subsection{Study limitations}

a. This study was limited to male and female counselors working in public schools of the Directorate of Education in the Kasbah of Salt for the year 2019-2020.

b. The generalization of the study results depends on the validity and reliability of the study tool. 


\section{Method and Procedures}

\subsection{Study Approach}

The study followed the descriptive survey method as the appropriate method for the nature of the study, as a tight questionnaire was applied, to achieve real results.

\subsection{The Study Populationand its Sample}

The study population consisted of all the female instructors who work in the Directorate of Education in the Kasbah of Salt for the academic year 2019-2020. They are (100) male and female counselors, the sample of the study consisted of (75) female and male counselors, that is, (0.75\%) of the study population, the sample was chosen randomly, and Table (1) shows the frequencies and percentages of the study sample according to gender variables, educational qualification, years of experience, and educational stage.

Table 1: Distribution of the study sample according to the variables

\begin{tabular}{|l|l|c|c|}
\hline Variable & Alternatives & $\mathbf{N}$ & Percentage \\
\hline \multirow{2}{*}{ Gender } & Male & 35 & $47 \%$ \\
\cline { 2 - 4 } & Female & 40 & $53 \%$ \\
\hline \multirow{2}{*}{ Experience } & Less than 10 years & 40 & $53 \%$ \\
\cline { 2 - 4 } & More than 10 years & 35 & $47 \%$ \\
\hline \multirow{2}{*}{ Educational qualification } & Bachelor degree & 50 & $67 \%$ \\
\cline { 2 - 4 } & Postgraduate & 25 & $33 \%$ \\
\hline \multirow{2}{*}{ Educational Stage } & Basic Stage & 60 & $80 \%$ \\
\cline { 2 - 4 } & Secondary Stage & 15 & $20 \%$ \\
\hline
\end{tabular}

\subsection{The Study Tool}

The researchers prepared the questionnaire based on their review of educational literature and related studies, such as the studies of Saqer (2009), Al-Hazaymeh (2014), Al-Mashaqabeh (2018), Hamdouna (2006) and Ghanima (2006), the tool consisted of two parts:

Part I: Personal data about gender, educational qualification, experience in education, and directorate.

Part II: It consists of (56) skills formulated in the form of items and distributed in four areas:

The first domain: (defensive skills to avoid the occurrence of a crisis) and included (11) items.

The second domain: (skills for planning to face the crisis) and included (13) items.

The third domain: (administrative skills(interventionist)to deal with the crisis during its occurrence) and included (18) items. items.

The fourth domain: (administrative skills (treatment) after the crisis ends) and it included (14)

The researcher adopted the Likert scale quintet: (very high, high, moderate, low and very low), and it corresponds to the numbers respectively $(1,2,3,4,5)$, where the number (5) represents the highest score of the item, and the number (1) represents the lowest score of the item.

\subsection{The Validity of the Tool}

The researcher verified the content validity, as the tool was presented to (6) arbitrators who are specialists in the field of management,(3) faculty members specialized in educational management, and (2) supervisors of educational counseling, they were asked to express their views on the extent of accuracy and linguistic integrity in formulating the items of the questionnaire, and the adequacy of 
the item for the domain included in it, and the deletion or addition of some items according to the observations of the arbitrators, and the number of items for the questionnaire in its initial form was (65) items, in light of the comments made by the arbitrators on the tool, the proposed amendments were made, and the tool became finalized, including (52) items.

\subsection{The Reliability of the Tool}

The reliability of the tool was verified by distributing it to (25) male and female principals outside the study sample, using the Cronbach Alpha. The reliability coefficient of the questionnaire's axes was calculated, as the reliability reached (o.88), and this indicates a high degree of reliability, which supports confidence in using the questionnaire to achieve the objectives of the study.

Table 2: Reliability coefficients of the study tool

\begin{tabular}{|l|c|}
\hline Domain & Reliability \\
\hline Preventive skills to avoid a crisis. & 0.88 \\
\hline Planning skills to face the crisis. & 0.88 \\
\hline Administrative (interventionist) skills to deal with a crisis while it occurs. & 0.93 \\
\hline Administrative skills (treatment) after the crisis ends. & 0.83 \\
\hline The tool as a whole. & 0.88 \\
\hline
\end{tabular}

\subsection{Correction of the Tool}

A pentacle scale is used (Very High, High, Moderate, Low, Very Low).The following numerical estimates $(5,4,3,2,1)$ were given to estimate the educational counselors' degree for counseling skills to deal with crises. The range of the scale was calculated as follows:

Calculating the mean of the relative weight to determine the degree of practice according to the pentacle scale, as 5,4,3,2,1, represents the relative weight values and the degree was determined according to the formula:

The value of the scale categories $=\frac{\text { Highest value of scale }- \text { the lowest value of scale, } 5-1}{\text { The number of scale categories } 5}=0.8$

Table 3: Skill Rating

\begin{tabular}{|l|c|}
\hline Degree of possessing & The value \\
\hline Very high & $4 \cdot 3-5$ \\
\hline High & $3 \cdot 5-4 \cdot 2$ \\
\hline Moderate & $2.7-3 \cdot 4$ \\
\hline Low & $1.9-2.6$ \\
\hline Very low & $1-1.8$ \\
\hline
\end{tabular}

4.7 Procedures for applying the study tool

The researchers conducted a series of procedures, including the following:

1. Review several previous studies that are related to the subject of the study, and related to the skills of school crisis management.

2. Prepare the study tool, and presenting it to several arbitrators to verify its validity and reliability.

3. Determine the study population and its sample.

4. Distribute the questionnaire to the study members to answer its items in the first semester of 2019-2020.

5. Collect questionnaires, in cooperation with school principals and educational counselors, in the Directorate of Education in the Kasbah of Salt, and the information was blanked in tables prepared for this purpose. 
6. Use of statistical software packages SPSS Social Sciences to conduct appropriate statistical treatments.

\subsection{The Study Variables}

The study included four independent variables and two dependent variables.

First: independent variables, which include:

1. Gender: male and female.

2. The educational qualification has two levels: 1 - Bachelor 2 - Postgraduate.

3. Experience in counseling: It has two levels: 1- Less than 10 years, 2- 10 years, or more.

4. The educational stage: It includes the basic stage, the secondary stage.

Second: The dependent variables: It includes the degree of school principals' possession of school crisis management skills.

\subsection{Statistical Methods}

Statistical methods that suit the variables of the study and its questions were used by entering information into the computer, and then analyzing it using the Statistical Package for Social Sciences (SPSS), where statistical methods were used of averages, iterations, percentages, and standard deviations to indicate the characteristics of the study sample and its variables, and the T-test analysis of variance to show the differences and the statistical significance of the variables.

\section{The Results of the Study and its Discussion}

5.1 Results of the first question: What is the degree to which principals of public schools in the Kasbah of Salt possess the skills of school crisis management from the viewpoint of the counselors?

To answer this question, the researcher extracted the arithmetic averages and the standard deviations of the educational counselors' estimates of the degree of school principal's possession of skills in school crisis management. The skills are arranged within each field according to their mean and standard deviations. Table (4) shows the mean and standard deviations for possessing the skills for each of the four domains.

Table 4: Mathematical averages and standard deviations for the fields of school crisis management skills arranged according to mathematical averages

\section{Domain}

Preventive skills to avoid a crisis.

Planning skills to face the crisis.

Administrative (interventionist) skills to deal with a crisis while it occurs.

Administrative skills (treatment) after the crisis ends.

The tool as a whole.

\begin{tabular}{cccc} 
Mean & $\begin{array}{c}\text { Standard } \\
\text { deviation }\end{array}$ & Degree & Rank \\
\hline 3.02 & 1.25 & Moderate & 4 \\
3.77 & 1.23 & High & 1 \\
3.07 & 1.39 & Moderate & 2 \\
3.06 & 1.41 & Moderate & 3 \\
3.23 & 1.38 & Moderate
\end{tabular}

It is seen from Table (4) The degree level principals possess the skills of school crisis management came as the average arithmetic mean (3:23), this means that the degree of possession came in all domains with an average degree, except for the second domain, which came in a high degree, and in the first rank with an average arithmetic value of $(3,77)$, and the third domain came in the second rank, where the arithmetic average reached (3.07), the fourth domain ranked third with an average of (3.06).In contrast, the first domain ranked fourth with a mean of (3.02). 
Table 5a: Means and standard deviations for each item in the tool within its domain. The first domain: preventive skills to avoid a crisis

\begin{tabular}{|c|c|l|c|c|c|}
\hline N & Rank & Item & Mean & $\begin{array}{c}\text { Standard } \\
\text { deviation }\end{array}$ & $\begin{array}{c}\text { Degree of } \\
\text { estimation }\end{array}$ \\
\hline 6 & 1 & The principal creates different teams to predict crises. & 3.32 & 1.09 & Moderate \\
\hline 9 & 2 & The principal scans the school environment to identify indicators of a possible crisis. & 3.29 & 1.10 & Moderate \\
\hline 3 & 3 & The principal analyzes indicators of a crisis. & 3.23 & 1.13 & Moderate \\
\hline 7 & 4 & The principal provides the necessary financial capabilities for the team's work. & 3.11 & 1.11 & Moderate \\
\hline 5 & 5 & The principal creates a complaint box to identify their concerns. & 3.09 & 1.14 & Moderate \\
\hline 1 & 6 & The principal organizes meetings with student leaders to identify student crises. & 3.01 & 1.12 & Moderate \\
\hline 11 & 7 & $\begin{array}{l}\text { In cooperation with the Parent Board, the principal works to reduce harmful habits such as } \\
\text { smoking, drugs, bullying, ...etc. }\end{array}$ & 2.99 & 1.18 & Moderate \\
\hline 2 & 8 & The principal studies the social phenomena and problems causing the crisis related to the school. & 2.91 & 1.20 & Moderate \\
\hline 8 & 9 & The principal benefits from experience and expertise in the local community to avoid crises. & 2.84 & 1.21 & Moderate \\
\hline 10 & 10 & $\begin{array}{l}\text { The principal addresses the quarrels between students and their teachers at school as they } \\
\text { happen. }\end{array}$ & 2.79 & 1.29 & Moderate \\
\hline 4 & 11 & The principal addresses the implications of family problems in families for students. & 2.65 & 1.40 & Moderate \\
\hline \multicolumn{2}{|l|}{ Overall average } & 3.02 & 1.25 & \\
\hline
\end{tabular}

The first domain: Preventive skills to avoid the occurrence of the crisis: It is evident from Table (5) that the arithmetic mean of the total principals' possession of preventive skills to avoid the occurrence of crises in public schools came with a degree of moderate practice, reaching (3.02),all the items of the domain obtained an average estimate, but item (6), which is, "The principal forms different teams to predict crises" came first, as it got a mean of (3.32), the researcher explains this result that the principals are practicing practices to avoid the occurrence of the crisis, even if this domain came at a moderate degree, but this confirms that the principal is continuously following up on all the happenings in his school, from forming teams to predict crises, to surveying the school environment to identify the indicators of the crisis in addition to forming a complaints box for students to identify their concerns, this moderate degree, even if it is low, is acceptable, and this may be due to the many burdens on the principal. It takes more time in routine work, daily tasks, and monitoring school activities, time is short for him, this result is consistent with the results of the Liming Study (2010), the Hazayma Study (2014) and the Saras study (2015) and it differs with the result of the Al-Mashaqaba Study (2018), the Hamdoun Study (2006) and the Saqr Study (2009).

Table 5b: The second domain: planning skills to face the school crisis

\begin{tabular}{|c|c|l|c|c|c|}
\hline N & Rank & Item & Mean & $\begin{array}{c}\text { Standard } \\
\text { deviation }\end{array}$ & $\begin{array}{c}\text { Degree of } \\
\text { estimation }\end{array}$ \\
\hline 16 & 1 & The director develops a crisis management plan in advance that he will use when the crisis strikes. & 4.17 & 1.04 & High \\
\hline 18 & 2 & In his management plan, the principal sets goals for school crisis management. & 4.09 & 1.09 & High \\
\hline 12 & 3 & The principal identifies the types of school crises students may be exposed to & 4.00 & 1.16 & High \\
\hline 20 & 4 & In the School Crisis Plan, the principal explains the necessary procedures to prevent crises. & 3.97 & 1.21 & High \\
\hline 25 & 5 & The headmaster forms a crisis management team to face the crises surrounding his school. & 3.90 & 1.23 & High \\
\hline 24 & 6 & The principal maintains a procedural plan to deal with the school crisis as it occurs. & 3.89 & 1.19 & High \\
\hline 13 & 7 & The principal engages teachers in planning and implementing a crisis response program. & 3.82 & 1.22 & High \\
\hline 22 & 8 & The principal provides a record of the crises that occurred in the school and how it can be faced. & 3.78 & 1.27 & High \\
\hline 15 & 9 & The principal prepares teachers and students psychologically for a positive response to crises. & 3.73 & 1.26 & High \\
\hline 17 & 10 & $\begin{array}{l}\text { The school administration determines the material and human capabilities required to deal with } \\
\text { school crises before, during and after they occur. }\end{array}$ & 3.68 & 1.31 & High \\
\hline 23 & 11 & The school administration establishes a system and regulations for safety and risk prevention. & 3.59 & 1.32 & High \\
\hline 19 & 12 & $\begin{array}{l}\text { The principal will seek help from outside the school when preparing school crisis management } \\
\text { plans. }\end{array}$ & 3.49 & 1.35 & High \\
\hline $14-$ & 13 & $\begin{array}{l}\text { In his plan, the principal shall specify a set of alternatives available at the time of the crisis, to } \\
\text { choose the optimum. }\end{array}$ & 3.41 & 1.34 & High \\
\hline $21-$ & 14 & The principal adopts time as an essential factor in making decisions when a crisis occurs & 3.32 & 1.36 & Moderate \\
\hline Overall average & 3.77 & 1.23 & High \\
\hline
\end{tabular}


The second domain: planning skills to face the school crises: It is clear from Table (5) that the arithmetic means of the total principals' possession of planning skills to face the school crises came with a high degree of practice, reaching (3.77), where item (16) came first and with an average score of (4.17) which states, "The director shall set a plan for crisis management in advance that he will use when the crisis occurs" while all the items came with a high degree of practice, except item (21) came with a moderate degree, as it reached (3.32) (which states: "The principal depends on the time component as an important factor in decision-making when the crisis occurs", the researcher explains that the items of this domain came with a high degree of possession among the principals, maybe due to the interest of the principals in the administrative plan and its preparation in a way that ensures dealing with crises inside the school, in addition to preparing school principals adequately for familiarity with what is planning clearly, and full clarity of the image among educational institutions, including the Ministry of Education, in the appropriate way to begin to educate principals on this type of skill, and benefit from it to serve the educational process, the results of this study were consistent with the results of Hamdouna study (2006), Al-Mashaqba study (2018), and Saqr's study (2009), which indicated that principals have skills to plan school crisis management with a high degree, the results of this study also differed with the results of the study of Al-Hazayma (2014) and the study of Al-Saras (2015), which indicated that the principals possess moderate skills in managing school crises.

Table 5c: The third domain: administrative (interventionist) skills to deal with the crisis while it occurs

\begin{tabular}{|c|c|l|c|c|c|}
\hline $\mathrm{N}$ & Rank & Item & Mean & $\begin{array}{c}\text { Standard } \\
\text { deviation }\end{array}$ & $\begin{array}{c}\text { Degree of } \\
\text { estimation }\end{array}$ \\
\hline $29-$ & 1 & The principal works to reduce tension between students and teachers at the school. & 3.31 & 1.12 & Moderate \\
\hline $33-$ & 2 & The principal sends reassurance to the school staff. & 3.27 & 1.16 & Moderate \\
\hline $26-$ & 3 & He encourages self-centered initiatives in times of crisis. & 3.24 & 1.17 & Moderate \\
\hline $31-$ & 4 & He uses the steps of scientific thinking in facing the crisis. & 3.21 & 1.22 & Moderate \\
\hline $35-$ & 5 & The school principal engages teachers in decision-making to resolve the crisis. & 3.19 & 1.21 & Moderate \\
\hline $37-$ & 6 & The school principal works to limit the spread of the crisis after a suitable period. & 3.14 & 1.26 & Moderate \\
\hline $27-$ & 7 & The principal draws on expertise from within the school to deal with crises. & 3.12 & 1.29 & Moderate \\
\hline $34-$ & 8 & The principal activatesthe principle of delegating powers to confront the crisis when it occurs. & 3.09 & 1.36 & Moderate \\
\hline $28-$ & 9 & The principal limits the spread of rumors to talk about the crisis so that it does not get worse. & 3.03 & 1.43 & Moderate \\
\hline $36-$ & 10 & The principal adopts an external communication policy to face the crisis. & 2.99 & 1.37 & Moderate \\
\hline $38-$ & 11 & The principal adopts the open-door communication policy to face the crisis. & 2.91 & 1.48 & Moderate \\
\hline $30-$ & 12 & The principal invests the financial and human capabilities to contain the crisis. & 2.75 & 1.51 & Moderate \\
\hline $32-$ & 13 & The principal makes quick and critical decisions when the crisis occurs. & 2.69 & 1.55 & Moderate \\
\hline Overall average & 3.07 & 1.39 & \\
\hline
\end{tabular}

The third domain: administrative (interventionist) skills to deal with the crisis during its occurrence: Table (5) shows that the arithmetic mean of the total principals' possession of planning skills to face school crises in this domain reached (3.02) and the level of a moderate degree of possession, all the items of this curriculum obtained a moderate degree, but item No. (29) came first with a mean of (3.31) which states "The school principal works to reduce tension between students and teachers in the school", while item (32) came last, with an average score of (2.69) and it states that "the school principal takes decisive and rapid decisions when the crisis occurs", the researcher explains this result that most principals realize the importance of reducing tension between students or between teachers or between students and teachers and spreading the spirit of tranquility among them so that the school remains embodied the spirit of familiarity and love among all and most school principals if not all of them have the skills of containment and sympathy and accept students and listen to them, consequently, their ability and skills in dealing with their crises when it occurs are acceptable, especially since most of these skills have been gained from training courses and exchange of experiences with others that are the core of successful educational management, and the axis upon 
which administrative relations are based and which require acceptable skills to master them, also, communication between school principals and the exchange of experiences through training courses in most schools would raise the degree of enthusiasm among principals in dealing with crises, although this interaction is still at a moderate level that requires advanced management skills, the results of this study are consistent with the results of Al-Hazaymeh study (2014), and Al-Saras study (2015) and differ with the result of Al-Mashaqbah study (2018) and Al-Zoubi study (2014) which indicated that school principals possess these skills with a high degree.

Table 5d: The fourth domain: Administrative skills (treatment) after the crisis ends

\begin{tabular}{|c|c|l|c|c|c|}
\hline N & Rank & Item & Mean & $\begin{array}{c}\text { Standard } \\
\text { deviation }\end{array}$ & $\begin{array}{c}\text { Degree of } \\
\text { estimation }\end{array}$ \\
\hline $48-$ & 1 & The principal assesses the plans used to deal with the crisis & 3.47 & 1.08 & High \\
\hline $44-$ & 2 & $\begin{array}{l}\text { The principal creates communication channels between the school and the educational } \\
\text { departments to address the effects of the crisis }\end{array}$ & 3.35 & 1.11 & Moderate \\
\hline $39-$ & 3 & The director allocates a budget to deal with the effects of the crisis & 3.29 & 1.39 & Moderate \\
\hline $50-$ & 4 & He studies the causes of the crisis to prevent its occurrence in the future & 3.22 & 1.38 & Moderate \\
\hline $41^{-}$ & 5 & He identifies with the teachers the negative aspects that cause the crisis & 3.18 & 1.41 & Moderate \\
\hline $46-$ & 6 & $\begin{array}{l}\text { The director continuously monitors the effects of the crisis to ensure that it does not recur in } \\
\text { the future }\end{array}$ & 3.13 & 1.51 & Moderate \\
\hline $49-$ & 7 & The principal prepares future plans to deal with the crisis & 3.09 & 1.30 & Moderate \\
\hline $52-$ & 8 & The principal draws lessons from the crises he faced in his school & 3.07 & 1.21 & Moderate \\
\hline $40-$ & 9 & The principal invests the situations resulting from the crisis in reform and development & 3.03 & 1.39 & Moderate \\
\hline $45-$ & 10 & The director develops an emergency plan to follow up on activities to address the future crisis & 2.99 & 1.41 & Moderate \\
\hline $42-$ & 11 & The principal activates students' activities that protect them from shocks & 2.91 & 1.51 & Moderate \\
\hline $47-$ & 12 & He provides a database that actively contributes to identifying the future crisis & 2.80 & 1.42 & Moderate \\
\hline $43-$ & 13 & The director runs media campaigns to explain the damage caused by the crisis & 2.72 & 1.43 & Moderate \\
\hline $51^{-}$ & 14 & He takes appropriate measures to practice normal activities & 2.58 & 1.34 & Low \\
\hline The & 3.06 & 1.41 & Moderate \\
\hline
\end{tabular}

The fourth domain: Administrative skills (treatment) after the crisis ends: It is evident from Table No. (5) that the arithmetic mean of the school total possession of administrative skills (treatment) after the crisis ends came with a moderate degree of possession as it reached (3.06), where item (48) obtained a high degree of possession, which reached (3.47), it states "The principal assesses the plans that were used in the face of the crisis", while item (51) came in the last rank and with a low degree of possession, which reached (2.58), and it states " The principal takes the appropriate procedures for practicing the usual activities "while all the items of the domain came with a moderate degree", the researcher explains this result to the fact that school principals have the administrative skills to deal with the crisis after its completion is a critical stage and requires administrative capabilities mastered by many principals in order to take all necessary measures to mitigate the impact of the crisis and limit its continuity, in addition to the principal's awareness of the harmful effects that crises leave on students 'souls, he is doing his best to mitigate them as required, therefore, the Ministry of Education was keen to have its administrative cadres in schools possess the skills of school crisis management, by motivating them to enroll in free courses that qualify them to obtain sufficient skills to fully exercise their administrative tasks and work, this result is consistent with the result of Al-Hazaymeh study (2014) and Al-Yahyawi study (2006), which indicated that the degree of possession of administrative skills after the end of the crisis came with a moderate degree, and it differs with the result of Al-Mashaqba study (2018), Saqr study (2009) and Hamdouna study (2006) that reached a high degree of possession. 
5.2 The second question: Are there statistically significant differences at the level of significance $(\alpha=$ 0.05 ) in the degree of possession of public schools' principals in the Kasbah of Salt of school crisis management skills from the viewpoint of counselors attributable to the gender variable?

To answer this question, arithmetic averages and standard deviations were calculated to know the effect of gender on the degree to which school principals have administrative skills in dealing with crises, and Table (6) illustrates this.

Table 6: Arithmetic averages and standard deviations for the effect of gender on the degree of principals' possession of administrative skills in dealing with crises

\begin{tabular}{|c|c|c|c|c|c|c|}
\hline Domain & Experience & $\mathrm{N}$ & Mean & $\begin{array}{l}\text { Standard } \\
\text { deviation }\end{array}$ & $\begin{array}{c}\text { "t" } \\
\text { value }\end{array}$ & Sig \\
\hline \multirow{2}{*}{ Preventive skills to avoid a crisis } & Male & 35 & 3.82 & 0.64 & \multirow{2}{*}{2.97} & \multirow{2}{*}{0.003} \\
\hline & Female & 40 & 4.01 & 0.61 & & \\
\hline \multirow{2}{*}{ Planning skills to face the school crisis } & Male & 35 & 3.96 & 0.62 & \multirow{2}{*}{2.82} & \multirow{2}{*}{0.005} \\
\hline & Female & 40 & 4.16 & 0.58 & & \\
\hline \multirow{2}{*}{$\begin{array}{l}\text { Administrative (interventionist) skills to deal with a } \\
\text { crisis as it occurs }\end{array}$} & Male & 35 & 3.69 & 0.64 & \multirow{2}{*}{3.19} & \multirow{2}{*}{0.002} \\
\hline & Female & 40 & 3.95 & 0.69 & & \\
\hline \multirow{2}{*}{ Administrative skills (treatment) after the crisis ends } & Male & 35 & 3.87 & 0.55 & \multirow{2}{*}{2.19} & \multirow{2}{*}{0.030} \\
\hline & Female & 40 & 4.06 & 0.68 & & \\
\hline \multirow{2}{*}{ Total degree } & Male & 35 & 3.84 & 0.61 & \multirow{2}{*}{3.12} & \multirow{2}{*}{0.001} \\
\hline & Female & 40 & 4.05 & 0.64 & & \\
\hline
\end{tabular}

The results of the variance analysis t-test show the responses of the sample members to the study domains by gender, that there are statistically significant differences for all domains of study attributed to gender and for the benefit of females, as the value of "T" on the total score reached (3.12) and at the level of significance ((o.oo1), the researchers explain this result to the fact that female principals adhere to more than one school administration instruction, and that they have sufficient time to manage school crises, in addition to that the females are more vigilant, cautious, follow-up and ready for any urgent matters that may occur in the school in addition to the principal's sense of follow-up and monitoring by the Directorate of Education and the local community and parents, this leads her to manage crises in her school with high skill until she proves her success in the administrative process, and the results of the study are consistent with the results of Khalil's study (2016) and this result differed with the result of the Hamdouna study (2006), Liming study (2010), Saqr study (2009), and Al-Mashaqaba study (2018) which indicated that there are no differences due to the gender variable.

5.3 The third question: Are there statistically significant differences at the level of significance (= 0.05 $=\alpha$ ) in the degree to which principals of public schools in the Kasbah of Salt possess school crisis management skills from the viewpoint of counselors attributable to the variable (experience)?

To answer this question, arithmetic averages and standard deviations were calculated to know the effect of experience on the degree of principals' possession of administrative skills in dealing with crises, and Table (7) illustrates. 
Table 7: Arithmetic averages and standard deviations for the effect of experience on the degree of principals' possession of administrative skills in dealing with crises

\begin{tabular}{|c|c|c|c|c|c|c|}
\hline Domain & Experience & $\mathrm{N}$ & Mean & $\begin{array}{l}\text { Standard } \\
\text { deviation }\end{array}$ & \begin{tabular}{c|}
$t "$ \\
value
\end{tabular} & Sig \\
\hline \multirow{2}{*}{ Preventive skills to avoid a crisis } & Less than 10 years & 35 & 2.75 & 1.11 & -12.38 & *0.03 \\
\hline & More than 10 years & 40 & 3.68 & 1.02 & & \\
\hline \multirow{2}{*}{ Planning skills to face the school crisis } & Less than 10 years & 35 & 2.62 & 1.15 & -10.49 & *0.02 \\
\hline & More than 10 years & 40 & 3.64 & 1.06 & & \\
\hline \multirow{2}{*}{$\begin{array}{l}\text { Administrative (interventionist) skills to deal with a } \\
\text { crisis as it occurs }\end{array}$} & Less than 10 years & 35 & 2.71 & 1.19 & -12.61 & $0.00^{*}$ \\
\hline & More than 10 years & 40 & 3.85 & 1.04 & & \\
\hline \multirow{2}{*}{ Administrative skills (treatment) after the crisis ends } & Less than 10 years & 35 & 2.72 & 1.22 & -11.01 & $0.00^{*}$ \\
\hline & More than 10 years & 40 & $3 \cdot 71$ & 1.01 & & \\
\hline \multirow{2}{*}{ Total degree } & Less than 10 years & 35 & 2.70 & 1.18 & -12.48 & $0.00^{*}$ \\
\hline & More than 10 years & 40 & 3.72 & 1.03 & & \\
\hline
\end{tabular}

The results of the variance analysis test $(\mathrm{T})$ for the responses of the sample members on the study domains according to the experience of the principal show that there are statistically significant differences for all domains of the study attributable to the experience, where the "t" calculated value was (-12.48) and the level of significance amounted to (o.oo) in favor of a category more than ten years, this indicates that the experience of the school principal is related to the degree of having skills in dealing with crises, and the researcher explains this result to the fact that the experience factor plays a vital role in the principal's acquisition of school crisis management skills, whereas, this group has deepened their experiences, experienced them, and familiarized themselves with practical practices that helped them to possess school management skills effectively, this result is consistent with the findings of the Khalil study (2016), and Saqr study (2009), which indicated that there are statistically significant differences in the degree of principals' possession of school crisis management skills due to experience, and the result differed with the result of the Hamadoun study (2006), which indicated that there were no differences attributed to the experience variable.

5.4 The fourth question: Are there statistically significant differences at the level of significance ( $\alpha=$ o.05) in the degree of public schools' principals in the Kasbah of Salt possessing school crisis management skills from the viewpoint of counselors attributable to the variable (educational qualification)?

To answer this question, arithmetic averages and standard deviations were calculated to know the effect of the educational qualification on the degree of school principals' possession of administrative skills in dealing with crises, and Table (8) shows that.

Table 8: Arithmetic averages and standard deviations of the sample members' responses on the study domains of the extent to which principals have administrative skills in dealing with crises and t-test results according to the educational qualification

\begin{tabular}{|c|c|c|c|c|c|c|}
\hline Domain & Experience & $\mathrm{N}$ & Mean & $\begin{array}{l}\text { Standard } \\
\text { deviation }\end{array}$ & $\begin{array}{c}\text { "t" } \\
\text { value }\end{array}$ & Sig \\
\hline \multirow{2}{*}{ Preventive skills to avoid a crisis } & Bachelor & 50 & 3.29 & 1.09 & -0.14 & 0.12 \\
\hline & Postgraduate & 25 & 3.32 & 1.17 & & \\
\hline \multirow{2}{*}{ Planning skills to face the school crisis } & Bachelor & 50 & 3.23 & 1.18 & 0.57 & ${ }^{*} 0.03$ \\
\hline & Postgraduate & 25 & 3.16 & 1.06 & & \\
\hline \multirow{2}{*}{$\begin{array}{l}\text { Administrative (interventionist) skills to deal with a } \\
\text { crisis as it occurs }\end{array}$} & Bachelor & 50 & 3.33 & 1.19 & -0.56 & 0.29 \\
\hline & Postgraduate & 25 & 3.42 & 1.25 & & \\
\hline \multirow{4}{*}{ Management skills (treatment) after the crisis ends } & Bachelor & 50 & 3.17 & 1.17 & -0.20 & 0.18 \\
\hline & Postgraduate & 25 & 3.21 & 1.12 & & \\
\hline & Bachelor & 50 & 3.26 & 1.18 & -0.24 & 0.59 \\
\hline & Postgraduate & 25 & 3.28 & 1.11 & & \\
\hline
\end{tabular}


The results indicate that there are no statistically significant differences at the level of significance $(\alpha \leq 0.05)$ in the degree of principals' possession of skills in dealing with crises according to the variable of the educational qualification based on the values of calculated " $\mathrm{T}$ " on the total degree which reached (- 0.24) and the level of significance (0.59), as well as in all domains except for the domain of planning skills to meet the school crises, in which the value of calculated " $\mathrm{T}$ " reached (0.57) at the level of significance (0.03) for the benefit of principals who hold a bachelor's degree, the researcher explains this result to the fact that the principals of different educational qualifications are graduates of one educational system, that they have the same academic background, and that all school principals, regardless of their qualifications, are subject to the same training and qualification during service, in addition, there is a gap between what is being studied and applied, and this result is consistent with the result of the Saqer study (2009) and differs with the result of the Khalil study (2016).

5.5 The fifth question: Are there statistically significant differences at the level of significance ( $\alpha=0.05)$ in the degree of directors of public schools in the Kasbah of Salt possessing school crisis management skills from the viewpoint of counselors attributable to the variable (educational stage)?

To answer this question, arithmetic averages and standard deviations were calculated to know the effect of the educational stage on the degree to which principals have administrative skills in dealing with crises, and table (9) illustrates this.

Table 9: Arithmetic averages and standard deviations of the sample members' responses on the study domains for the effect of the educational stage on the degree of principals' possession of administrative skills in dealing with crises and test results $(\mathrm{T})$

\begin{tabular}{|c|c|c|c|c|c|c|}
\hline Domain & Experience & $\mathbf{N}$ & Mean & $\begin{array}{l}\text { Standard } \\
\text { deviation }\end{array}$ & \begin{tabular}{c|} 
"t" \\
value
\end{tabular} & Sig \\
\hline \multirow{2}{*}{ Preventive skills to avoid a crisis } & Basic Stage & 60 & 3.38 & 1.12 & 2.58 & ${ }^{*} 0.89$ \\
\hline & Secondary Stage & 15 & 3.14 & 1.16 & & \\
\hline \multirow{2}{*}{ Planning skills to face the school crisis } & Basic Stage & 60 & 3.28 & 1.18 & 2.38 & ${ }^{*} 0.41$ \\
\hline & Secondary Stage & 15 & 3.05 & 1.17 & & \\
\hline \multirow{2}{*}{$\begin{array}{l}\text { Administrative (interventionist) skills to deal with a } \\
\text { crisis as it occurs }\end{array}$} & Basic Stage & 60 & 3.42 & 1.13 & 2.41 & $0.92 *$ \\
\hline & Secondary Stage & 15 & 3.22 & 1.16 & & \\
\hline \multirow{2}{*}{ Administrative skills (treatment) after the crisis ends } & Basic Stage & 60 & $3 \cdot 31$ & 1.15 & 2.15 & $0.58^{*}$ \\
\hline & Secondary Stage & 15 & 3.11 & 1.16 & & \\
\hline \multirow{2}{*}{ Total degree } & Basic Stage & 60 & 3.35 & 1.12 & 2.51 & $0.91^{*}$ \\
\hline & Secondary Stage & 15 & 3.13 & 1.15 & & \\
\hline
\end{tabular}

$(\alpha \leq 0.05)$

The results indicate that there are no statistically significant differences at the level of significance $(\alpha \leq 0.05)$ in the degree that principals have the skills to deal with crises according to the variable of the educational stage, as the value of calculated " $\mathrm{T}$ " on the total score was (2.51) and the level of significance (0.91), as well in all domains, the researcher explains this result that the instructions, regulations, and laws are unified in all schools, whether primary or secondary, in addition to the similarity of principals of primary and secondary schools in educational and academic qualification, training courses and school equipment, and the material and moral support they receive from the Ministry of Education, so the result was that there were no differences between the two stages, this result is consistent with the result of the Saqer study (2009). 


\section{Recommendations}

1. There is a need for male and female principals to have skills in dealing with school crises, and how to employ them during the administrative process.

2. To hold training courses and mentoring programs for school principals to equip them with school crisis management skills.

3. To develop psychological and educational counseling methods and to activate the role of the educational counselor helps the principal discover any problems before they escalate into a school crisis.

4. To create an organized database for everything related to school crises.

5. To put the curriculum of school crisis management within the university courses in the specializations that can work in the field of school management.

6. To plan programs for preparing principals at the level of higher diploma and graduate studies include courses to possess crisis management skills to achieve the desired goals of the educational process.

7. To conduct more studies to identify the reality of principals having the skills to deal with school crises and linking them with many variables such as academic specialization, age, and school type.

8. To conduct studies dealing with the strategies of confronting school crises in public schools from the viewpoint of principals and teachers.

9. To conduct studies that address the degree to which school principals possess school crisis management skills from the teachers and educational supervisors' viewpoint.

\section{References}

Abdullah, F. (2012). Crisis and Disaster Management, Kuwait: Quortas Publishing House.

Abu Qahf, A. (2002). "Director's Guide to Crisis Management in Delegation of Authority - Features of Reform Administrative Contracts - Crisis Management", Alexandria, The New University Publishing House.

Adamson, A. \& Peacock, G. (2007). Crisis response in the public school: A survey of school psychologists experience and perception, journal of psychology in the school, 44(8), 749-764.

Al-Araji, A. \& Daqasmeh, M. (200o). "Crisis Management: A Field Study of the Availability of Crisis Management Elements from the Viewpoint of Workers in Supervisory Positions in the Greater Amman Municipality." Riyadh, Institute of Public Administration, 39(4).

Al-Hazaymeh, M. (2014). School principals' abilities to deal with crises in Irbid Governorate, unpublished Master Thesis, Yarmouk University, Irbid, Jordan.

Al-Qadhafi, Z. (2017). "Strategies for Confronting the Educational Crisis in Secondary Education Schools in Libya", Girls College of Arts and Educational Sciences, Ain Shams University.Journal of Scientific Research, 1(18), 671-685.

Al-Shraideh, H. \& Al-Araji, A. (2003). "The relationship between some variables of crisis management as viewed by decision-makers in secondary schools", Riyadh, King Faisal University Scientific Journal (Humanities and Administrative Sciences), 4(1), 425-438.

Al-Mashaqaba, M. (2018). "The degree of school principals in Zarqa Governorate have the skill of managing school crises from their point of view," Journal of Educational and Psychological Sciences, 2 (29), 318-329.

Al-Yahyawi, S. (2006). "Crisis Management in Governmental Middle Girls' Schools in Al-Madinah AlMunawwarah,” Refereed Research, Riyadh, King Fahd University.

Al-Zoubi, M. (2014). The degree of availability of the elements of crisis management in the directorates of education in the Irbid Governorate from the viewpoint of the department heads in it, Journal of Dirasat, $41(1), 2383-2364$.

Ashour, M. (2011). Degree of perception of department heads at Yarmouk University for the availability of elements of crisis management, Umm Al-Qura University Journal for Educational and Psychological Sciences, $3(1), 156-167$.

Bron, C. \& Patterson, S. (2012). "Bullying and school crisis Intervention. International Journal of Humanities and social science, 2 ( 7 ), $72-81$ 
Dumitriu, C. \& Donia, M. (2009). Crisis Management the case of school shooting, case study Islas Malvinas" middle school national library and archives Canada- isbn:987298109563.

El-Gammal, A. \&Hakim, T. (1983). "Leadership Behavior of Principals of Basic Education Schools from their and their teachers' point of view." Dar Al-Thaqafa: Cairo.

Faraj, S. (2011). General education school principals practice the skills of school crisis management from the viewpoint of principals and teachers in Makkah Al-Mukarramah, Educational Journal, College of Education, Sohag University, 29(1), 355-428.

Gainey, B. (2009). Crisis management new role in the educational setting, journal of educational strategies, $82(6), 267-274$.

Gaza, A. (2009). Degree of availability of crisis management skills to the principals of UNRWA schools in Gaza and ways to develop them: Master Thesis, College of Education, Islamic University, Gaza

Ghanima, R. (2012). Educational Crisis Management Requirements in Damascus, Unpublished Master Thesis, University of Damascus, Syria.

Hamdouna, H. (2006). "The practice of the headmaster of a high school skill of crisis management in Gaza Governorate", unpublished master's thesis, Gaza Islamic University.

Khalil, E. (2016). The reality of crisis management in Palestinian government schools from the viewpoint of principals in the southern West Bank, Journal of Educational Sciences, 2(1), 77-84.

Liming, R. (2010). Stress sources and coping strategies of secondary public-school principals, unpublished doctoral, University of Denver, internet, No. AAC991358.

Obaid, A. (2010). A National Plan to Address Emergencies, Journal of Administration, 25(4), 9-36.

Onyike Maggaret Odu(2014). "Management of student crisis in higher institution of learning in Nigeria " International letters of social and Humanities Sciences, 4 (1), 233-238.

Rabee, I. (2002). "Crisis Management: Causes and Treatment", Cairo, Dar Al-Fikr Al-Arabi.

Rabee, H. (2006). The Successful School Director, 1st edition, Amman Arab Society Library.

Rasas, M. (2015). The reality of crisis management in private schools in the governorates of Bethlehem and Ramallah and Al-Bireh from their principals and teachers' viewpoint, unpublished Master Thesis, Al-Quds University, Palestine.

Wilson, M. \&Keith, T. (2007). Crisis, management in school, Evidence-based prevention. Journal of Educational Enquiry, 7 (1), 1-31. 